\title{
Pengaruh Model Pembelajaran Creative Problem Solving Berbantuan Eksperimen Terhadap Kompetensi Pengetahuan IPA Siswa Kelas V
}

\author{
Ni Pt Lisa Safitri ${ }^{1}$, I Kt Ardana ${ }^{2}$ \\ ${ }^{12}$ Prodi Pendidikan Guru Sekolah Dasar, FIP \\ Universitas Pendidikan Ganesha, Singaraja, Indonesia \\ e-mail: putu.lisa.safitri@undiksha.ac.id ${ }^{1}$, iketut.ardana@undiksha.ac.id ${ }^{1}$
}

\begin{abstract}
Abstrak
Penelitian ini bertujuan untuk mengetahui pengaruh model pembelajaran Creative Problem Solving berbantuan Eksperimen terhadap kompetensi pengetahuan IPA siswa kelas V SD. Penelitian ini merupakan penelitian eksperimen semu dengan rancangan kelompok non-ekuivalen control group design. Populasi pada penelitian ini ialah seluruh siswa kelas V SD N Gugus 1 Kuta Utara, yang terdiri dari 14 kelas secara keseluruhan berjumlah 523 orang. Penentuan sampel dalam penelitian menggunakan teknik random sampling kelas VA SD No. 1 Dalung sebanyak 41 siswa sebagai kelompok kelas eksperimen dan kelas VB SD No.2 Dalung sebanyak 34 siswa sebagai kelompok kelas kontrol. Data kompetensi pengetahuan IPA siswa dikumpulkan dengan instrumen tes objektif pilihan ganda biasa sebanyak 30 butir soal yang sudah divalidasi. Selain itu nilai rata-rata gain skor kelompok siswa yang dibelajarkan melalui model pembelajaran Creative Problem Solving berbantuan Eksperimen $\bar{X}=0,47>\bar{X}=0,35$ rata-rata gain skor kelompok siswa yang dibelajarkan secara konvensional. Hasil analisis uji-t menunjukkan nilai $t_{\text {hitung }}=3,833>t_{\text {tabel }}(a=0,05, d k=73)=$ 2,000 sehingga $\mathrm{H}_{0}$ ditolak dan $\mathrm{Ha}$ diterima sehingga terdapat perbedaan yang signifikan antara siswa kelompok eksperimen dan kelompok kontrol. . Sesuai dengan hasil tersebut dapat disimpulkan model pembelajaran Creative Problem Solving Berbantuan Eksperimen berpengaruh terhadap kompetensi pengetahuan IPA siswa kelas V SD N Gugus 1 Kuta Utara Tahun Ajaran 2018/2019
\end{abstract}

Kata Kunci: creative problem solving, eksperimen, konvensional

\begin{abstract}
The purpose of this research was to know the effect of Creative Problem Solving learning model assisted with Experiment toward the natural science competency on $5^{\text {th }}$ grade students of SD N Gugus 1 Kuta Utara in academic year 2018/2019. This research was a quasi-experimental with nonequivalent control group design. The population in this research was all the $5^{\text {th }}$ grade students which were consisted of 14 classes with 523 students. The sample was selected by using random sampling with randomization of existing classes, then a lottery was conducted to determine the experimental group and control group. Therefore, class VA SD No. 1 Dalung with 41 students was selected as experimental group and class VB SD No. 2 Dalung with 34 students was selected as control group. The mean score of the students who were taught by using Creative Problem Solving learning model assisted with Experiment was higher than the students who were taught by using conventional learning model, $\bar{X}=0,47>\bar{X}=0,35$. The result of $t$-test analysis showed that $t_{\text {count }}=3,833>t_{\text {table }}$ $(\alpha=0.05 . d f=73)=2,000$ so that the $H_{0}$ was rejected and Ha was accepted. Based on the result, it could be concluded that Creative Problem Solving learning model assisted with Experiment influenced the natural science competency on $5^{\text {th }}$ grade students of SD N gugus 1 Kuta Utara
\end{abstract}

Keywords: creative problem solving, experiment, conventional

\footnotetext{
${ }^{*}$ Corresponding author.

Received 20 January 2020, Accepted 20 March 2020; Available online 5 Appril 2020 (C) 2020 MI All Rights Reserved
} 


\section{Pendahuluan}

Pada era globalisasi ini pendidikan merupakan suatu kebutuhan yang utama bagi manusia. Dalam menghadapi persaingan global yang sudah mulai berkembang saat ini, pendidikan menjadi suatu bekal yang penting bagi setiap insan manusia. Melalui pendidikan, peserta didik dapat mengembangkan segala potensi yang dimilikinya. Dalam UU No. 20 Tahun 2003 tentang Sistem Pendidikan Nasional: pendidikan adalah usaha sadar dan terencana untuk mewujudkan suasana belajar dan proses pembelajaran agar peserta didik secara aktif mengembangkan potensi dirinya untuk memiliki kekuatan spiritual keagamaan, pengendalian diri, kepribadian, kecerdasan, akhlak mulia, serta keterampilan yang diperlukan dirinya, masyarakat, bangsa dan negara.

Melalui pendidikan, kreativitas seseorang akan terpacu untuk terus berinovasi melalui ilmu pengetahuan. Pendidikan sering pula dijadikan tolak ukur kemajuan dan kesejahteraan suatu negara. Oleh karena itu, pentingnya meningkatkan kualitas pendidikan demi kemajuan bangsa dan negara. Selain itu pendidikan hendaknya berorientasi pada pengembangan seluruh aspek potensi peserta didik, yakni aspek spiritual, sosial, pengetahuan, dan keterampilan. Dengan memperhatikan aspek-aspek tersebut, tujuan pendidikan nasional bisa tercapai. Tujuan pendidikan nasional sudah tertera dalam Undang-Undang Nomor 20 Tahun 2003 tentang Sistem Pendidikan Nasional, pasal 3 yakni mengembangkan potensi peserta didik agar menjadi manusia yang beriman dan bertakwa kepada Tuhan Yang Maha Esa, berakhlak mulia, sehat, berilmu, cakap, kreatif, mandiri dan menjadi warga negara yang demokratis serta bertanggung jawab.

Dalam dunia pendidikan, kurikulum merupakan dasar dari penyelenggaraan pendidikan. Dalam undang-undang RI nomor 20 tahun 2003, Bab I Pasal 1 ayat 19, kurikulum diartikan "seperangkat rencana dan pengaturan mengenai tujuan, isi, dan bahan pelajaran serta cara yang digunakan sebagai pedoman penyelenggaraan kegiatan pembelajaran untuk mencapai tujuan pendidikan tertentu". Kurikulum yang terbaru yang digunakan dalam pendidikan Indonesia adalah Kurikulum 2013. "Kurikulum 2013 bertujuan untuk mempersiapkan manusia Indonesia agar memiliki kemampuan hidup sebagai pribadi dan warga negara yang beriman, produktif, kreatif, inovatif, dan afektif serta mampu berkontribusi pada kehidupan bermasyarakat, berbangsa, bernegara, dan peradaban dunia" (Kunandar, 2015:16). Pergantian kurikulum yang terjadi dalam sistem pendidikan di Indonesia tentunya mengalami banyak perubahan. Kurikulum merupakan suatu pedoman dalam penyelenggaran kegiatan pembelajaran yang memiliki fungsi dan kedudukan di masing-masing jenjang pendidikan.

Kurikulum 2013 dirancang untuk memberikan pengalaman belajar seluas-luasnya bagi siswa dalam mengembangkan pengetahuan yang dimiliki. Dalam kegiatan pembelajaran seringkali ditemui proses pembelajaran yang terlihat guru lebih aktif dari siswanya. Hal ini membuat siswa tidak mendapatkan kesempatan untuk mengemukakan gagasan mereka dalam mengikuti kegiatan pembelajaran yang kedepan bisa membuat siswa menjadi sangat pasif. Dalam kurikulum 2013 siswa dituntut untuk lebih aktif dan guru berperan sebagai fasilitator bagi siswa. Karena siswa dituntut untuk menjadi lebih aktif dalam kegiatan pembelajaran maka diperlukan suatu inovasi yang memang benar-benar mampu membangkitkan keaktifan siswa.

Peranan pendidik dalam mencerdaskan dan meningkatkan kualitas peserta didik juga perlu diperhatikan. Posisi seorang guru dalam dunia pendidikan sangatlah penting, maka sumber daya manusia (SDM) yang unggul adalah hal mutlak dalam proses pembelajaran. Seorang guru harus memenuhi standar pendidikan yang harus dicapai dengan memiliki kualifikasi akademik, kompetensi dan sertifikasi sesuai dengan persyaratan untuk setiap jenis dan jenjang pendidikan tertentu. Guru sebagai orang yang membelajarkan siswa juga dituntut 
untuk menjadi seorang guru yang kompeten dalam dunia pendidikan dilihat dari kompetensi yang harus dimilikinya yakni kompetensi pedagogik, kepribadian, profesional, dan sosial yang baik.

Pada saat observasi di Sekolah Dasar, ada beberapa permasalahan terkait proses belajar mengajar di kelas. Masih banyaknya siswa yang mengalami kesulitan dalam memahami muatan materi IPA yang berdampak pada kompetensi pengetahuannya. Selain itu jumlah siswa yang terlalu banyak dalam satu kelas membuat kebanyakan siswa menjadi sulit fokus untuk mengikuti kegiatan pembelajaran. Hal inilah yang menimbulkan rendahnya minat belajar siswa di sekolah yang kemudian berdampak pada hasil belajar siswa dilihat dari segi kognitif, afektif maupun psikomotor.

Muatan materi IPA memiliki peranan penting dalam pendidikan. Menurut Trianto (2012: 136) "IPA adalah suatu kumpulan teori yang sistematis, penerapannya secara umum terbatas pada gejala -gejala alam, lahir dan berkembang melalui metode ilmiah seperti observasi dan eksperimen serta menuntut sikap ilmiah seperti rasa ingin tahu, terbuka, jujur, dan sebagainya". Adanya muatan materi IPA di Sekolah Dasar yang terintegrasi dalam tematik, siswa diajarkan untuk mampu memecahkan permasalahan yang berkaitan dengan kehidupan sehari-harinya.

Dalam proses belajar mengajar, banyak model pembelajaran yang dapat mengaktifkan siswa dalam proses pembelajaran. Salah satu alternatif model pembelajaran tersebut adalah dengan menggunakan model pembelajaran Creative Problem Solving. Menurut Bakhruddin (dalam Shoimin,2014:56) "Creative Problem Solving (CPS) merupakan variasi dari pembelajaran dengan pemecahan masalah melalui teknik sistematik dalam mengorganisasikan gagasan kreatif untuk menyelesaikan suatu permasalahan". Dalam model ini siswa lebih dituntut untuk kreatif dalam memecahkan suatu permasalah dan mengemukakan ide-idenya. Namun dalam kegiatan belajar mengajar, model pembelajaran Creative Problem Solving belum pernah digunakan di Sekolah Dasar yang berada di Gugus 1 Kuta Utara.

Model pembelajaran Creative Problem Solving menjadi alternatif model pembelajaran yang dapat digunakan untuk meningkatkan minat belajar siswa. Di dalam model ini, siswa diajak untuk mengembangkan gagasan atau ide kreatifnya dalam menyelesaikan suatu masalah. Siswa bisa berlatih untuk berpikir secara kritis dan ilmiah dalam menyelesaikan masalah didalam kehidupan sehari-hari. Pada model pembelajaran Creative Problem Solving, siswa tidak hanya duduk diam namun setiap siswa mendapatkan kesempatan dalam memberikan pendapatnya tentang suatu permasalahan. Siswa bebas dalam mengemukakan ide kreatifnya untuk menemukan berbagai bentuk strategi pemecahan suatu masalah.

Tujuan model pembelajaran Creative Problem Solving yakni untuk membantu mengembangkan dan mengekplorasi pengetahuan IPA siswa secara lebih luas dengan memberikan siswa kebebasan untuk mengemukakan gagasan atau ide kreatif yang dimilikinya. Tentunya dalam menggunakan model Creative Problem Solving, guru hanya sebagai fasilitator untuk siswa. Guru sebagai pendamping dan mengarahkan setiap kegiatan yang akan dilakukan oleh siswa.

Adapun langkah-langkah model pembelajaran Creative Problem Solving. Tahap (1) klarifikasi masalah, tahap (2) pengungkapan pendapat, tahap (3) evaluasi dan pemilihan, tahap (4) implementasi. Model pembelajaran Creative Problem Solving memilki beberapa kelebihan, seperti yang dikatakan Shoimin (2014) adapun kelebihan dari model pembelajaran Creative Problem Solving yaitu (a) Melatih siswa untuk mendesain suatu penemuan. (b) Berpikir dan bertindak kreatif. (c) Memecahkan masalah yang dihadapi secara realistis. (d) Mengidentifikasi dan melakukan penyelidikan. (e) Menafsirkan dan mengevaluasi hasil pengamatan. 
Eksperimen menjadi salah satu kegiatan yang menarik dalam proses belajar mengajar. Melalui kegiatan eksperimen siswa dapat membuktikan suatu teori yang diperolehnya dan menerapkannya dalam kehidupan sehari-hari. Menurut Iru dan La Ode (2012) eksperimen dimaksudkan bahwa guru dan siswa mencoba mengerjakan sesuatu dengan mengamati setiap prosesnya dan hasil pekerjaannya yang dilakukan secara sistematis. Di dalam kegiatan eksperimen siswa diajak untuk melakukan suatu percobaan yang terkait dengan materi ajar yang diperolehnya. Hal ini dapat memicu minat siswa untuk belajar dan mengembangkan pengetahuannya secara lebih optimal.

Dalam kompetensi pengetahuan IPA, siswa masih belum mampu mengembangkan kemampuan berpikirnya dengan baik. Hal ini yang menyebabkan kompetensi pengetahuan menjadi menurun, pengalaman belajar siswa memberi pengaruh terhadap pengetahuannya. Apabila siswa memperoleh pengalaman belajar yang optimal maka kompetensi pengetahuannya akan bekembang dan memperoleh hasil belajar baik pula. Model pembelajaran yang sesuai dengan kondisi dan situasi belajar siswa dapat merangsang siswa untuk lebih aktif akan mampu memberikan dampak yang positif bagi kompetensi pengetahuan siswa.

Dari berbagai permasalahan tersebut, maka dilakukan penelitian tentang "Pengaruh Model Pembelajaran Creative Problem Solving Berbantuan Eksperimen Terhadap Kompetensi Pengetahuan IPA Siswa Kelas V SD N Gugus 1 Kuta Utara Tahun Ajaran 2018/2019".

Tujuan dari penelitian ini adalah Untuk mengetahui pengaruh model pembelajaran Creative Problem Solving berbantuan Eksperimen terhadap kompetensi pengetahuan IPA siswa kelas V SD N Gugus 1 Kuta Utara Tahun Ajaran 2018/2019

\section{Metode}

Jenis penelitian yang dilakukan dalam penelitian ini adalah penelitian kuantitatif dengan desain ekperimen yaitu quasi eksperimen (Eksperimen Semu). "Desain ini mempunyai kelompok kontrol, tetapi tidak bisa sepenuhnya mengontrol variabel-variabel luar yang mempengaruhi pelaksanaan eksperimen" (Sugiyono, 2017:77). Hal ini dikarenakan kemampuan peneliti dalam mengamati perilaku siswa sangat terbatas terutama ketika siswa berada di luar sekolah (rumah), peneliti juga tidak memiliki kemampuan untuk mengetahui persepsi siswa terhadap perlakuan secara pasti. Adapun rancangan eksperimen penelitian ini adalah sebagai berikut.

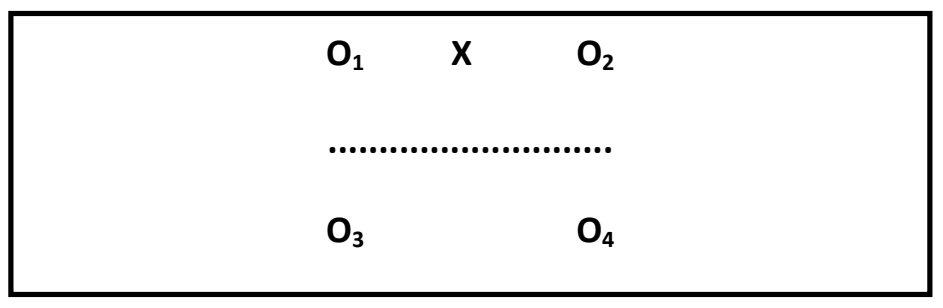

Gambar0 1.

Desain Penelitian Eksperimen Semu Menggunakan“Nonequilevalent Control Group Design” (Sumber: Sugiyono, 2017:79) 
Keterangan :

$\mathrm{O}_{1}=$ Pretest pada kelompok eksperimen

$\mathrm{O}_{2}=$ Posttest pada kelompok eksperimen

$\mathrm{O}_{3}=$ Pretest pada kelompok kontrol

$\mathrm{O}_{4}=$ Pottest pada kelompok kontrol

$\mathrm{X}=$ Perlakuan dengan model pembelajaran pembelajaran

Solving berbantuan eksperimen

Populasi dari penelitian ini adalah seluruh kelas V (lima) SD N Gugus 1 Kuta Utara tahun ajaran 2018/2019 yang terdiri dari 14 kelas dalam 7 Sekolah Dasar jumlah siswa adalah 523 orang. Teknik pengambilan sampel pada penelitian ini adalah random sampling, Agung (2014:71). Pemilihan sampel penelitian ini tidak megundi individu melainkan kelas. Setelah diundi untuk memperoleh dua sampel penelitian, maka terpilihlah yakni SD No.1 Dalung dan SD No.2 Dalung. Kemudian melakukan pengundian lagi untuk menentukan kelas $V$ yang dijadikan sampel penelitian maka terpilihlah kelas VA SD No.1 Dalung dan kelas VB SD No.2 Dalung menjadi sampel penelitian. Setelah dilakukan pengundian lagi maka kelas VA SD No. 1 Dalung sebagai kelas eksperimen dan kelas VB SD No. 2 Dalung sebagai kelas kontrol.

Pelaksanaan penelitian ini terdiri dari tiga tahapan yaitu, tahap persiapan, tahap pelaksanaan, dan tahap akhir. Pada tahapan persiapan eksperimen ini, kegiatan yang dilakukan , yakni: (1) Melakukan wawancara dengan kepala Gugus 1 Kuta Utara dan beberapa guru kelas $\mathrm{V}$ di masing-masing sekolah yang ada di gugus tersebut, untuk mengetahui ada atau tidaknya kelas unggulan di SD N yang ada di Gugus 1 Kuta Utara. (2) Mempersiapkan pembelajaran model pembelajaran Creative Problem Solving berbantuan eksperimen yang akan digunakan untuk membelajarkan kelas eksperimen. (3) Mengkonsultasikan instrumen penelitian pretest dan posttest bersama guru kelas dan dosen pembimbing. (4) Mengkonsultasikan RPP, dan media pembelajaran bersama guru kelas dan dosen pembimbing. (5) Mengadakan uji coba instrumen penelitian. (6) Menentukan sampel penelitian berupa kelas dari populasi yaitu dengan teknik random sampling. (7) Melakukan pengundian untuk menentukan kelompok eksperimen dan kelompok kontrol . (8) Memberikan pretest kepada sampel penelitian yang terpilih sebagai kelompok eksperimen dan kelompok kontrol untuk mengetahui kemampuan awal siswa. Selanjutnya tahap pelaksanaan, saat pelaksanaan eksperimen kegiatan yang ditempuh adalah (1) Memberikan perlakuan pada kelas eksperimen berupa model Pembelajaran Creative Problem Solving berbantuan eksperimen. Memberikan perlakuan pada kelas kontrol berupa pembelajaran secara konvensional menggunakan pendekatan saintifik. (2) Perlakuan diberikan sebanyak 6 kali di kelas eksperimen. Jumlah perlakuan yang diberikan telah disesuaikan dengan jam pelajaran terkait materi dalam penelitian ini yang telah diatur dalam kurikulum dan silabus. (3) Memberikan posttest pada akhir eksperimen, baik untuk kelompok eksperimen maupun kelompo kontrol. Saat tahap akhir eksperimen kegiatan yang ditempuh adalah (1) Menganalisis data hasil penelitian. (2) Melakukan uji hipotesis.

Metode pengumpulan data yang digunakan dalam penelitian ini dikumpulkan dengan metode tes. Kegiatan pengumpulan data dilaksanakan pada siswa kelas V SD N Gugus 1 Kuta Utara yang menjadi anggota sampel. Data yang dikumpulkan dalam penelitian adalah data tentang kompetensi pengetahuan IPA. Instrumen yang digunakan dalam pengumpulan data kompetensi pengetahuan IPA siswa berupa butir tes yaitu tes kompetensi pengetahuan IPA. Instrumen ini digunakan untuk mengukur kemampuan kognitif siswa baik kelompok eksperimen, maupun kelompok kontrol. Jenis tes yang digunakan pada penelitian ini berupa tes objektif dalam bentuk pilihan ganda biasa dengan 4 pilihan jawaban ( $a, b, c$ atau d) yang 
mengandung satu jawaban benar. Setiap item soal diberikan skor 1 bila siswa menjawab soal dengan benar (jawaban disesuaikan dengan kunci jawaban) dan skor 0 bila siswa menjawab salah. Skor setiap jawaban dijumlahkan dan jumlah tersebut menjadi skor variabel kompetensi pengetahuan IPA. Setelah instrumen disusun maka selanjutnya dilakukan validasi agar dapat digunakan sebagai instrumen penelitian. Tes dapat dikatakan baik sebagai alat ukur, harus memenuhi syarat ketepatan (validitas) dan keajegan atau ketepatan (reliabilitas). Untuk itu, sebelum tes tersebut digunakan terlebih dahulu diuji validitas, daya beda indeks, kesukarannya dan reliabilitas.

Selanjutnya menentukan indeks kesukaran, Arikunto (2015) menyatakan bahwa soal yang baik adalah soal yang tidak terlalu mudah atau tidak terlalu sukar. Soal yang terlalu mudah ialah tidak membuat siswa untuk mempertinggi usaha dalam memecahkannya. Sebaliknya soal yang terlalu sukar akan menyebabkan siswa menjadi putus asa dan tidak mempunyai semangat untuk mencoba lagi karena di luar jangkauannya. Tingkat kesukaran dapat dipandang sebagai kesanggupan atau kemampuan siswa menjawab tes yang diberikan. Bisa juga dikatakan bahwa tingkat kesukaran adalah bilangan yang menunjukan proporsi peserta tes yang menjawab betul butir soal yang diberikan. Tingkat kesukaran suatu butir soal dinyatakan dengan bilangan yang disebut dengan indeks kesukaran (difficulty indexs). Indeks kesukaran berkisar antara nilai 0,00 sampai dengan 1,00. Soal dengan indeks kesukaran 0,00 berarti butir soal tersebut terlalu sukar, sebaliknya indeks kesukaran soal mendekati 1,00 berarti soal tersebut terlalu mudah.

Setelah data dikumpulkan, data itu kemudian diolah atau dianalisis. Sugiyono (2017:147) menyatakan "analisis data merupakan kegiatan setelah data seluruh responden atau sumber data lainnya terkumpul". Teknik analisis yang digunakan untuk menganalisis data dalam penelitian ini adalah teknik analisis statistik inferensial. Statistik inferensial digunakan untuk menganalisis data yang dinormalisasi dari hasil pretest dan posttest. Untuk menguji hipotesis penelitian digunakan statistik inferensial yaitu uji-t. Sebelum dijumlah sebagai teknik analisis terlebih dahulu di uji prasyarat analisis yakni uji normalitas dan uji homogenitas.

\section{Hasil dan Pembahasan}

Setelah diberikan perlakuan sebanyak 6 kali pada kelas eksperimen dan kelas kontrol, maka dalam penelitian ini dikelompokkan menjadi dua, yaitu kelas eksperimen adalah siswa yang dibelajarkan menggunakan model pembelajaran Creative Problem Solving berbantuan Eksperimen pada siswa kelas V SD No.1 Dalung, sedangkan kelas kontrol adalah siswa yang dibelajarkan dengan pembelajaran konvensional pada siswa kelas V SD No.2 Dalung.

Berdasarkan hasil analisis kelompok eksperimen yaitu kelas VA SD No.1 Dalung memiliki rata-rata gain skor kompetensi pengetahuan IPA siswa kelompok eksperimen yaitu, 0,47 . GSn maksimal pada kelompok eksperimen yaitu 0,75 dan GSn minimal yaitu 0,14. Varians data kompetensi pengetahuan IPA pada kelompok eksperimen yaitu 0,020 dan standar deviasi 0,14 . Sedangkan hasil analisis kelompok kontrol kelas VB SD No. 2 Dalung diperoleh rata-rata gain skor kompetensi pengetahuan IPA siswa kelompok kontrol yaitu, 0,35. GSn maksimal pada kelompok kontrol yaitu 0,57 dan Gsn minimal yaitu 0,14. Varians data kompetensi pengetahuan IPA pada kelompok kontrol yaitu 0,017 dan standar deviasi 0,13. Dari data tersebut menunjukkan bahwa kelas eksperimen melalui model pembelajaran Creative Problem Solving berbantuan eksperimen memiliki rata-rata kompetensi pengetahuan IPA lebih tinggi daripada kelas kontrol yang dibelajarkan dengan pembelajaran konvensional.

Uji prasyarat dilakukan terlebih dahulu sebelum uji hipotesis menggunakan uji-t. Uji prasyarat tersebut meliputi uji normalitas dan uji homogenitas varians. Uji normalitas yang 
digunakan dalam penelitian ini menggunakan uji kolmogorov-smirnov. Berdasarkan hasil uji normalitas kelompok eksperimen diperoleh diperoleh perbandingan nilai $\mid \mathrm{FT}$-Fs | terbesar = $0,130<$ nilai tabel kolmogorov-smirnov $=0,212$. Berdasarkan hasil tersebut maka $\mathrm{HO}$ dapat dinyatakan diterima dan Ha dinyatakan ditolak. Sehingga dapat disimpulkan bahwa sebaran data kompetensi pengetahuan IPA pada kelompok eksperimen berdistribusi normal. Berdasarkan hasil uji normalitas kelompok kontrol diperoleh perbandingan nilai | FT-Fs | terbesar $=0,161<$ nilai tabel kolmogorov-smirnov $=0,227$. Berdasarkan hasil tersebut maka $\mathrm{HO}$ dapat dinyatakan diterima dan $\mathrm{Ha}$ dinyatakan ditolak. Sehingga dapat disimpulkan bahwa sebaran data kompetensi pengetahuan IPA pada kelompok kontrol berdistribusi normal.

Setelah data berdistribusi normal maka dilanjutkan dengan Uji homogenitas dilakukan untuk menunjukkan bahwa perbedaan yang terjadi pada uji hipotesis benar-benar terjadi akibat adanya perbedaan antar kelompok, bukan sebagai akibat perbedaan dalam kelompok. Uji homogenitas varians dalam penelitian ini menggunakan uji $F$. Dari hasil analisis, diperoleh $F_{\text {hitung }}=1,18$ sedangkan $F_{\text {tabel }}$ pada taraf signifikansi $5 \%$ dengan dk pembilang $41-1=40$ dan dk penyebut 34-1 $=33$ maka $F_{\text {tabel }}=1,76$. Hal ini berarti $F_{\text {hitung }}=1,18<F_{\text {tabel }}=1,76$ sehingga data kedua kelompok memiliki varians yang homogen. Berdasarkan hasil uji prasyarat yang terdiri dari uji normalitas dan uji homogenitas varians, maka dapat disimpulkan bahwa kedua data kelompok sampel ialah berdistribusi normal dan memiliki varians yang homogen.

Hasil uji prasyarat menunjukkan bahwa data kelompok kelas eksperimen dan kelas eksperimen berdistribusi normal serta memiliki varians yang homogen. Karena data tersebut sudah memenuhi uji prasyarat maka dilanjutkan dengan uji $t$ untuk uji hipotesis. Adapun hipotesis yang akan diuji yaitu tidak terdapat perbedaan yang signifikan kompetensi pengetahuan IPA antara kelompok siswa yang dibelajarkan melalui model pembelajaran Creative Problem Solving berbantuan Eksperimen dengan kelompok siswa yang dibelajarkan menggunakan pembelajaran konvensional pada siswa kelas V SD N Gugus 1 Kuta Utara Tahun Ajaran 2018/2019. Berdasarkan hasil perhitungan uji-t, diperoleh $t_{\text {hitung }}=3,833$ dan untuk taraf signifikansi $5 \%$ dengan $\mathrm{dk}=73$ diperoleh $t_{\text {tabel }}=2,000$. Dengan demikian, kelompok nilai $t_{\text {hitung }}=3,833>t_{\text {tabel }}=2,000$ sehingga $H_{0}$ ditolak. Rekapitulasi hasil analisis uji-t kelompok sampel penelitian ini disajikan dalam tabel 1 berikut.

Tabel 01 Hasil Analisis Uji-t Kelompok Sampel Penelitian

\begin{tabular}{|c|c|c|c|c|c|c|c|c|}
\hline No & Sampel & $\begin{array}{l}\text { Rata- } \\
\text { rata }\end{array}$ & Varians & Dk & $\mathbf{N}$ & $t_{\text {hitung }}$ & $t_{\text {tabel }}$ & Kesimpulan \\
\hline 1 & $\begin{array}{l}\text { Kelas } \\
\text { Eksperimen }\end{array}$ & 0,47 & 0,020 & 73 & 41 & 3,833 & 2,000 & $\mathrm{H}_{0}$ ditolak \\
\hline 2 & Kelas kontrol & 0,35 & 0,017 & & 34 & & & \\
\hline
\end{tabular}

Berdasarkan uji hipotesis yang diperoleh $t_{\text {hitung }}=3,833$ sedangkan pada taraf signifikansi $5 \%$ dan dk 73 diperoleh nilai $t_{\text {tabel }}=2,000$ sehingga $t_{\text {hitung }}=3,833>t_{\text {tabel }}=2,000$. Dengan demikian maka $\mathrm{H}_{0}$ ditolak. Hal ini menunjukkan terdapat perbedaan yang signifikan kompetensi pengetahuan IPA antara kelompok siswa yang dibelajarkan melalui model pembelajaran Creative Problem Solving berbantuan Eksperimen dengan kelompok siswa yang dibelajarkan secara konvensional pada siswa kelas V SD N Gugus 1 Kuta Utara Tahun Ajaran 2018/2019.

Pengaruh antara penggunaan model pembelajaran Creative Problem Solving dengan pembelajaran konvensional dapat dilihat dari hasil statistik deskriptif antara kedua kelompok sampel. Rata-rata gain skor nilai kompetensi pengetahuan IPA siswa pada kedua kelompok 
yaitu pada kelompok eksperimen 0,47 dan pada kelompok kontrol yaitu 0,35. Berdasarkan hasil perhitungan statistik menunjukkan bahwa rata-rata gain skor kompetensi pengetahuan IPA siswa kelompok eksperimen lebih tinggi dibandingan dengan rata-rata kompetensi gain skor pengetahuan IPA siswa kelompok kontrol. Hasil tersebut menunjukkan bahwa hasil belajar siswa pada kelompok eksperimen lebih tinggi dibandingkan dengan hasil belajar siswa pada kelas kontrol dalam kompetensi pengetahuan IPA.

Berdasarkan hasil wawancara dengan kepala Gugus SD N 1 Kuta Utara, dapat dinyatakan bahwa kelas V di SD N Gugus 1 Kuta Utara memiliki kemampuan setara dan tidak terdapat sekolah unggulan maupun non unggulan. Setelah siswa pada kelompok eksperimen diberikan perlakuan berupa pembelajaran dengan menggunakan model pembelajaran Creative Problem Solving berbantuan eksperimen dan siswa pada kelompok kontrol yang diberikan pembelajaran secara konvensional maka diperoleh skor kompetensi pengetahuan IPA siswa yang berbeda. Perbedaan skor kompetensi pengetahuan yang diperoleh siswa disebabkan oleh perlakuan yang diberikan pada kedua kelompok sampel. Pada kelompok eksperimen, kegiatan pembelajaran muatan materi IPA dibelajarkan menggunakan model pembelajaran Creative Problem Solving berbantuan eksperimen berjalan dengan optimal, kondusif dan siswa cenderung lebih aktif serta antusias mengikuti kegiatan pembelajaran. Hal ini dikarenakan model pembelajaran Creative Problem Solving berbantuan eksperimen merupakan suatu inovasi pembelajaran yang memberi kesempatan untuk siswa belajar lebih aktif dan belajar mengungkapkan ide atau gagasan yang dimilikinya secara kreatif serta menyelesaikan suatu permasalahan melalui kegiatan percobaan. Selama kegiatan pembelajaran berlangsung siswa lebih aktif dan antusias karena kegiatan pembelajaran menggunakan model pembelajaran Creative Problem Solving berbantuan eksperimen menciptakan lingkungan belajar yang kondusif, aktif, menyenangkan dengan adanya kegiatan percobaan.

Berdasarkan proses analisis data yang dilakukan dapat diketahui bahwa model pembelajaran Creative Problem Solving berbantuan eksperimen berpengaruh terhadap kompetensi pengetahuan IPA siswa. Hal ini sesuai dengan yang dijelaskan oleh Uno dan Mohamad (2011:223) menyatakan bahwa "model 'Creative Problem Solving' adalah suatu model pembelajaran yang melakukan pemusatan pada pembelajaran dan keterampilan pemecahan masalah, yang diikuti dengan penguatan keterampilan".

Pada kelompok kontrol siswa diberikan pembelajaran secara konvensional. Pembelajaran pada kelompok eksperimen dan kelompok kontrol hampir sama yakni menggunakan pendekatan saintifik, karena kurikulum 2013 mengharapkan kegiatan pembelajaran dilaksanakan dengan menggunakan pendekatan saintifik. Namun yang membedakan yakni di kelompok eksperimen siswa dibelajarkan menggunakan model pembelajaran Creative Problem Solving berbantuan eksperimen sedangkan pada kelompok kontrol hanya menerapkan pembelajaran konvensional atau pendekatan saintifik saja sehingga suasana pembelajaran menjadi monoton dan menyebabkan siswa kurang semangat dalam mengikuti kegiatan pembelajaran.

Berdasarkan hasil uji hipotesis yang diperoleh pada penelitian ini menunjukkan bahwa $t_{\text {hitung }}=3,833$ sedangkan pada taraf signifikansi $5 \%$ dan $\mathrm{dk} 73$ diperoleh nilai $t_{\text {tabel }}=2,000$ sehingga $t_{\text {hitung }}=3,833>t_{\text {tabel }}=2,000$. Dengan demikian hasil penelitian ini juga mendukung hasil penelitian sebelumnya yang dilakukan oleh Siswadi (2014) menunjukkan bahwa model Creative Problem Solving berbantuan media grafis berpengaruh terhadap hasil belajar IPA siswa kelas V SD Gugus VI Pangeran Diponogoro Denpasar Barat Tahun Ajaran 2013/2014. Hasil analisis data menunjukkan terdapat perbedaan yang signifikan hasil belajar IPA antara siswa yang dibelajarkan menggunakan model Creative Problem Solving berbantuan media 
grafis dengan siswa yang dibelajarkan menggunakan pembelajaran konvensional. Dilihat dari hasil analisis dengan uji-t, diperoleh $t_{\text {hitung }}=2,500>t_{\text {tabel }}(=0,05,70)=2,000$.

\section{Simpulan dan Saran}

Berdasarkan hasil analisis data dan pembahasan yang telah dipaparkan diperoleh hasil uji hipotesis dengan menggunakan uji-t dimana diperoleh $t_{\text {hitung }}=5,998$ dan dengan taraf signifikansi $5 \%, \mathrm{dk}=41+32-2=71$ diperoleh $t_{\text {tabel }}=2,000$. Dengan demikian, nilai $t_{\text {hitung }}>t_{\text {tabel }}$ sehingga Ho ditolak. Nilai rata-rata kompetensi pengetahuan matematika kelompok eksperimen $=81,4$, sedangkan nilai rata-rata kompetensi pengetahuan matematika kelompok kontrol $=56,9$. Sehingga nilai rata-rata kompetensi pengetahuan matematika kelompok eksperimen lebih tinggi dibandingkan kompetensi pengetahuan matematika kelompok kontrol yaitu 81,4 > 56,9. Jadi dapat disimpulkan bahwa model pembelajaran langsung (direct instruction) memberikan pengaruh terhadap kompetensi pengetahuan matematika kelas IV SDN Gugus Letda Made Putra Denpasar Utara.

Berkenaan dengan hasil penelitian yang diperoleh maka dapat diajukan beberapa saran sebagai berikut. Saran yang dapat disampaikan berdasarkan penelitian yang telah dilakukan adalah sebagai berikut : 1) Kepada Siswa diharapkan siswa dapat lebih aktif, kreatif, dapat selalu meningkatkan rasa ingin tahu melalui bertanya apabila ada yang belum di pahami, agar pengembangan pola pikir siswa dapat lebih luas, kritis dan inovatif. 2) Kepada guru, disarankan untuk lebih kreatif dalam memberikan fasilitas pendukung berupa inovasi pelaksanaan pembelajaran dengan menerapkan model pembelajaran langsung (direct instruction) berbantuan media gambar sehingga tercipta pembelajaran yang bermakna dan semangat siswa untuk belajar meningkat. 3) Kepala sekolah disarankan agar dapat menggunakan hasil penelitian ini sebagai pendukung sumber belajar guru dalam meningkatkan kualitas pembelajaran dengan menciptakan pembelajaran yang menyenangkan di sekolah. 4) Peneliti lain disarankan agar memanfaatkan hasil penelitian ini sebagai referensi untuk melaksanakan

\section{Daftar Pustaka}

Agung, A. A. Gede. 2014. Buku Ajar Metode Penelitian Pendidikan. Yogyakarta: Aditya Media Publishing

Arikunto, Suharsimi. 2015. Dasar-Dasar Evaluasi Pendidikan. Jakarta: Bumi Aksara

Dantes, 2017. Desain Eksperimen dan Analisis Data. Depok: PT Rajagrafindo Persada

Iru, La dan La Ode Safiun Arihi. 2012. Analisis Penerapan Pendekatan, Metode, Strategi. dan Model Model Pembelajaran. DIY: Multi Presindo

Kunandar. 2015. Penilaian Autentik (Penilaian Hasil Belajar Peserta Didik Berdasarkan Kurikulum 2013) Suatu Pendekatan Praktis Disertai dengan Contoh. Jakarta: Rajawali Pers

Shoimin, Aris. 2014. 68 Model Pembelajaran Inovatif Dalam Kurikulum 2013. Yogyakarta: ArRuzz Media 
Siswadi, I B Indra Pratama Siswadi. 2014. "Pengaruh model pembelajaran creative problem (CPS) Solving berbantuan media grafis terhadap hasil belajar siswa kelasV SD Gugus VI Pangeran Diponogoro Denpasar Barat Tahun Ajaran 2013/2014". Vol: 2 No: 1 Tahun (hlm 1-12). Tersedia pada: http://ejournal.undiksha.ac.id p

Sugiyono. (2017). Metode Penelitian Kuantitatif, Kualitatif, dan R\&D. Bandung : Alfabeta, CV

Trianto. 2012. Model pembelajaran terpadu: konsep, strategi, dan implementasinya dalam kurikulum tingkat satuan pendidikan (KTSP). Jakarta: Bumi Aksara

Undang-Undang Republik Indonesia Nomor 20 Tahun 2003 Tentang Sistem Pendidikan Nasional. Jakarta: Departemen Pendidikan Nasional

Uno, Hamzah B. dan Nurdin Mohamad. 2012. Belajar dengan Pendekatan Pailkem: Pembelajaran Aktif, Inovatif, Lingkungan, Kreatif, Efektif, Menarik. Jakarta: Bumi Aksara 